Proceedings in Cases Relating to Hospital Medical and Dental Staff (HM(61)112). Originally circulated to health authorities in 1961 by the Ministry of Health, this document remains unchanged since that time. The fact that the health service has moved apace, as has society, seems to have gone unnoticed. The document establishes, though by no means clearly, a series of steps starting from preliminary investigation for the establishment of a prima facie case and progressing through to a formal inquiry. These inquiries are formal and legalistic, requiring a high standard of proof, with many rights enshrined for the consultant under investigation, including the ability to comment on the proceedings, to make a plea of mitigation, and to appeal to the Secretary of State. In practice this results in years of delay and excessive cost to the various health authorities. There are currently approximately 40 NHS consultants suspended on full pay pending such inquiries, and this could add up to a cost of $£ 4000000$ to the health service. There is certainly a case to be made for reviewing this disciplinary procedure which benefits neither the doctor nor the service. Until we have a clearer system which has the support of consultants and health authorities, difficult and often painful cases will continue to arise in which problems of competence may be confused with difficult relationships and interpersonal problems.

Teaching districts and university based medical schools have different disciplinary procedures. The teaching districts' consultant contracts are district based and disciplinary procedures receive the attention of the district medical officer rather than being directed to the region, while teaching hospitals may direct problems through the university disciplinary procedure. Cases concerning professional conduct and competence in general practice will be directed to the family practitioner committee.

\section{Conclusion}

It seems that the procedure for dealing with a sick doctor has improved in recent years, although the reasons for doctors' greater vulnerability to particular health problems have received little attention, especially in medical schools. Where illness is not an issue, however, the position is clearly unsatisfactory and in need of change.

From How To Do It: 2, a new collection of useful advice on topics that doctors need to know about but won't find in the medical textbooks. Just published, price $\mathfrak{E 6 . 9 5}$, this is a companion volume to the popular How To Do It: 1 , also published by the $B M F$.

\title{
Basic Molecular and Cell Biology
}

\section{Stem cells in normal growth and disease}

\author{
T M DEXTER
}

Mature blood cells have a short life span. Erythrocytes, for example, are functionally active for only a few months before being sequestered and destroyed, and granulocytes persist for only a few hours. In practical terms this means that about $3.7 \times 10^{11}$ - that is, 370000 million-mature blood cells are lost each day. ${ }^{1}$ Cell loss of a similar magnitude undoubtedly occurs in other regenerating systems such as the skin and intestine. ${ }^{2}$ Obviously, these cells need to be replaced to maintain the integrity of the various body tissues, and some mechanism is required to ensure that the means of cell production is maintained throughout a normal lifetime. The mature cells of the regenerating tissues are highly specialised cells which are themselves incapable of further growth. Their numbers must therefore be replaced through proliferation and development of more primitive cells, known as stem cells.

\section{Origin of stem cells}

Two models have been proposed to explain the persistence of stem cells throughout life..$^{3-5}$ The first model suggests that a fixed number of primitive cells is laid down during embryogenesis to supply the body's needs throughout its lifetime. These cells are randomly recruited into proliferation, differentiation, and

Paterson Institute for Cancer Research, Christie Hospital and Holt Radium Institute, Manchester M20 9BX

T M DEXTER, DSC, MRCPATH, professor of haematology development as required-like the recruitment of oocytes. As these stem cells proliferate there is a progressive loss in their ability to produce more stem cells or to act as founder cells of the various mature cell lineages - in other words, the stem cell pool declines with age. The second model also suggests that a small population of stem cells arises during embryonic development but that these cells can reproduce themselves (undergo self renewal) to produce daughter cells which retain the same proliferative and developmental potential as the original parental cells. In this model, therefore, the recruitment of stem cells into proliferation and development does not necessarily lead to a reduction in the number of stem cells. The weight of evidence strongly supports this second model of a self renewing stem cell population. ${ }^{67}$ The critical point here is that birth and death processes must be balanced: the input of cells into the stem cell compartment must be balanced by exit from the stem cell compartment as a consequence of differentiation and death. ${ }^{8}$ It follows that a prolonged, albeit minor, perturbation in this balance would have dramatic consequences. If too many stem cells underwent self renewal then the production of mature cells would be reduced to life threatening levels; if too many stem cells underwent differentiation and development then the small pool of stem cells would rapidly become exhausted. It is clear, however, that some degree of flexibility must be built into the system to allow for the extra proliferative demands imposed by stress conditions such as hypoxia or wound healing. How, then, are the regenerating tissues organised? Many lessons have been learnt from the haemopoietic system, and this will be used as an example, although a similar cellular organisation is seen in the skin epidermis and the intestinal epithelium. 


\section{Haemopoietic system}

Haemopoietic stem cells arise in the yolk sac and then migrate to the fetal liver and subsequently to the developing bones. ${ }^{9} \mathrm{~W}$ ithin the bones the stem cells associate with a complex non-haemopoietic stromal cell matrix, which provides the milieu for further proliferation and development. The mature cells produced then traverse the endothelium lining the marrow sinuses and are released into the circulation. ${ }^{10}$ Extensive work has shown that the different kinds of blood cells-the neutrophils, monocytes and macrophages, eosinophils, basophils, erythrocytes, megakaryocytes (platelets), B lymphocytes, and $T$ lymphocytes-are all derived from a common stem cell which is resident in the marrow. ${ }^{11-13}$ In other words, the stem cell is multipotent. The self renewal ability of haemopoietic stem cells is readily seen during marrow transplantation. For example, about 50000 marrow cells taken from a mouse and transferred into a potentially lethally irradiated recipient mouse will fully reconstitute the haemopoietic system. The reconstituted animals then have a normal life span, producing mature blood cells of donor origin. Since 50000 marrow cells represent only $1 / 5000$ of the total marrow reserve it follows that a normal mouse must have at least 5000 stem cells. In fact, the number is probably much higher, and a figure of 500000 has been proposed..$^{5}$ It is difficult to extrapolate these figures to man, but it is likely that stem cells are present in a similar concentration. It is clear that in order to produce the numbers of mature cells necessary to maintain normal steady state haemopoiesis an extensive cellular amplification must occur during development. Also, to produce the variety of mature cell types the stem cells must undergo differentiation into the various lineage restricted cell types. This may be readily detected using in vitro assay systems. ${ }^{15-17}$

When marrow cells are removed from the body and plated on to nutrient growth media they can be induced to proliferate and form colonies containing various cell types. Some of these colonies contain multiple lineages-for example, erythroid cells, neutrophils, and megakaryocytes - and are obviously derived from multipotent cells. Other colonies contain mature cells representative of only one or two cell lineages and are derived from bipotent or unipotent progenitor cells. By means of these in vitro systems it has been possible to build up a cell hierarchy and define the nature of the various differentiated cells (figure). Clearly, the cellular amplification occurs as a consequence of proliferation and development of the differentiated "committed" progeny of the stem cells.

\section{Growth promoting agents}

These in vitro systems have also been used to isolate and characterise a range of growth promoting agents and other factors which modulate proliferation and development of the blood forming cells. All of the growth promoting agents have one thing in common: their continued presence is essential for the survival of haemopoietic cells in vitro. Marrow cells that are removed from the body and cultured in nutrient media in the absence of growth factors die. In the presence of growth factors they survive, proliferate, and mature into functional blood cells. ${ }^{15-19}$

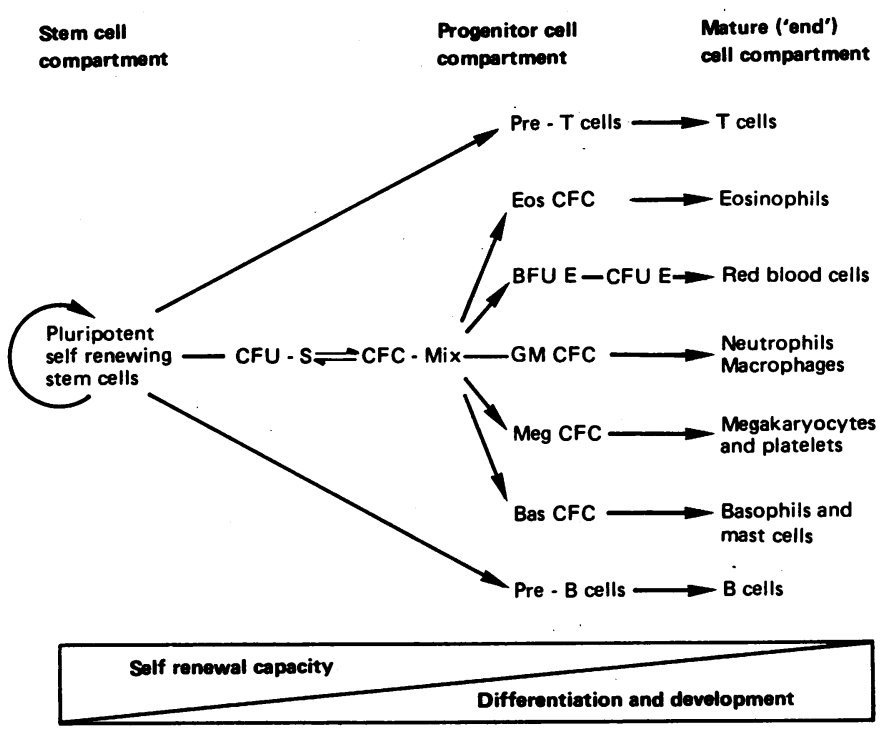

Differentiation and development of stem cells. CFU-S =murine spleen colony forming cell; $\mathrm{CFC}-\mathrm{Mix}=\mathrm{a}$ multipotential cell producing mixed myeloid cell colonies in vitro; GM CFC=granulocyte/macrophage colony forming cell; $B F U E=a$ primitive erythroid progenitor cell; $\mathrm{CFU} E=$ a more mature erythroid progenitor cell; Eos $\mathrm{CFC}=$ eosinophil colony forming cell; $\mathrm{Bas} \mathrm{CFC}=$ basophil/ mast cell progenitor; $\mathrm{Meg} \mathrm{CFC}=$ megakaryocyte colony forming cell.

The type of blood cells produced depends on the growth promoter, used (see table). Interleukin 3, for example, can stimulate proliferation and development of multipotent stem cells as well as more differentiated progenitor cells, which are restricted to the neutrophil, macrophage, erythroid, eosinophil, megakaryocyte, and mast cell lineages. Some growth promoters are restricted to a certain lineage-for example, macrophage colony stimulating factor will stimulate only the development of monocytes and macrophages from the appropriate progenitor cells. Other growth promoters, such as granulocyte and macrophage colony stimulating factor, are intermediate in their target cells. In other words, haemopoiesis in vitro can be induced by a variety of growth promoting agents, which show various degrees of restriction, but also extensive overlap, in their target cells.

Growth factors active on haemopoietic stem cells and committed cells

\begin{tabular}{|c|c|c|c|c|c|c|c|c|c|c|c|c|c|}
\hline \multirow[b]{2}{*}{ Growth factor } & \multirow[b]{2}{*}{ Species } & \multicolumn{2}{|c|}{ Purified } & \multirow{2}{*}{$\begin{array}{l}\text { Molecular } \\
\text { weight } \\
\text { (kilodalton) }\end{array}$} & \multirow[b]{2}{*}{$\begin{array}{l}\text { Stem } \\
\text { cells }\end{array}$} & \multicolumn{7}{|c|}{ Target cells } & \multirow[b]{2}{*}{ Activity in vivo } \\
\hline & & Native & Cloned & & & GM CFC & BFU E & Eos CFC & $\begin{array}{l}\text { Meg } \\
\text { CFC }\end{array}$ & $\begin{array}{l}\text { Mast } \\
\text { cells }\end{array}$ & CFU E & $\begin{array}{l}\text { Mature } \\
\text { cells }\end{array}$ & \\
\hline Interleukin 3 & $\left\{\begin{array}{l}\text { Mouse } \\
\text { Human }\end{array}\right.$ & \pm & $\begin{array}{l}+ \\
+\end{array}$ & $\begin{array}{l}26 \\
20\end{array}$ & $\begin{array}{l}+ \\
+\end{array}$ & $\begin{array}{l}+ \\
+\end{array}$ & $\begin{array}{l}+ \\
+\end{array}$ & $\stackrel{+}{\text { ND }}$ & $\stackrel{+}{\text { ND }}$ & $\stackrel{+}{\text { ND }}$ & $\stackrel{ \pm}{\mathrm{ND}}$ & $\stackrel{ \pm}{\mathrm{ND}}$ & $\begin{array}{l}\text { Yes } \\
\text { ND }\end{array}$ \\
\hline $\begin{array}{l}\text { Granulocyte and macrophage } \\
\text { colony stimulating factor }\end{array}$ & $\left\{\begin{array}{l}\text { Mouse } \\
\text { Human }\end{array}\right.$ & $\begin{array}{l}+ \\
+\end{array}$ & $\begin{array}{l}+ \\
+\end{array}$ & $\begin{array}{l}14 \\
19\end{array}$ & \pm & $\begin{array}{l}+ \\
+\end{array}$ & \pm & $\begin{array}{l}+ \\
+\end{array}$ & $\begin{array}{l}+ \\
+\end{array}$ & $\overline{-}$ & - & $\begin{array}{l}+ \\
+\end{array}$ & $\begin{array}{l}\text { Yes } \\
\text { Phase I/II trials under way }\end{array}$ \\
\hline $\begin{array}{l}\text { Granulocyte colony stimulating } \\
\text { factor }\end{array}$ & $\left\{\begin{array}{l}\text { Mouse } \\
\text { Human }\end{array}\right.$ & $\begin{array}{l}+ \\
+\end{array}$ & $\begin{array}{l}+ \\
+\end{array}$ & $\begin{array}{l}24 \\
19\end{array}$ & $\overline{-}$ & $\begin{array}{l}+(\mathbf{G}) \\
+(\mathbf{G})\end{array}$ & $\overline{-}$ & $\overline{-}$ & $\cdot$ & $\begin{array}{l}- \\
-\end{array}$ & - & $\begin{array}{l}+ \\
+\end{array}$ & $\begin{array}{l}\text { Yes } \\
\text { Phase I/II trials under way }\end{array}$ \\
\hline $\begin{array}{l}\text { Macrophage colony stimulating } \\
\text { factor } \\
\text { Interleukin } 4\end{array}$ & $\left\{\begin{array}{l}\text { Mouse } \\
\text { Human } \\
\text { Mouse }\end{array}\right.$ & $\begin{array}{l}+ \\
+ \\
+\end{array}$ & $\begin{array}{l}+ \\
+ \\
+\end{array}$ & $\begin{array}{l}45 \\
26 \\
24\end{array}$ & $\begin{array}{l}- \\
-\end{array}$ & $\begin{array}{l}+(\mathbf{M}) \\
+(\mathbf{M}) \\
-\end{array}$ & $\begin{array}{l}- \\
-\end{array}$ & $\begin{array}{l}- \\
+\end{array}$ & $\begin{array}{l}- \\
- \\
-\end{array}$ & $\begin{array}{l}- \\
\overline{ \pm}\end{array}$ & $\begin{array}{l}- \\
- \\
-\end{array}$ & $\begin{array}{c}+ \\
+ \\
\text { ND }\end{array}$ & $\begin{array}{l}\text { Yes } \\
\text { Phase I/II trials under way } \\
\text { ND }\end{array}$ \\
\hline Erythropoietin & $\left\{\begin{array}{l}\text { Mouse } \\
\text { Human }\end{array}\right.$ & - & + & $\begin{array}{l}\text { Not known } \\
\text { Not known }\end{array}$ & - & - & $\begin{array}{l}- \\
-\end{array}$ & - & - & $\overline{-}$ & + & - & $\begin{array}{l}\text { ND } \\
\text { Yes, phase I/II trials now } \\
\text { complete }\end{array}$ \\
\hline Interleukin 1 & Human & + & + & 17 & Studie & in murine $s$ & stem; syr & ergises with & growth & tors & & - & $\begin{array}{l}\text { Yes (radioprotective in } \\
\text { mice) }\end{array}$ \\
\hline
\end{tabular}


In some respects the overlap in biological activities could be considered to be redundant. This may not be the case, however, since in the haemopoietic system in particular (and probably other systems in general) we are dealing with interactive cellular networks, where the outcome of a response depends on the growth promoting agents to which the cells are exposed. Furthermore, it is important to bear in mind that these different factors not only facilitate proliferation and development of immature cells but also activate the function of mature cells. ${ }^{1620}$.Granulocyte and macrophage colony stimulating factor and macrophage colony stimulating factor, for example, enhance the ability of macrophages to engulf and destroy bacteria and protozoa; granulocyte and macrophage colony stimulating factor and granulocyte colony stimulating factor induce increased protein synthesis and superoxide generation in mature neutrophils; and eosinophil colony stimulating factor facilitates maturation and mobilisation of eosinophils in response to nematode infections. Thus after local infection it is likely that the first line of defence entails the production of these growth factors by the surrounding tissue cells to recruit and activate circulating leucocytes. In more aggressive infections circulating endotoxins derived from bacteria act as a powerful stimulus for the production and release of various growth factors which, as their concentrations rise, begin to influence haemopoiesis in the marrow. The actual growth promoter produced probably reflects the inducing stimulus -that is, viral or bacterial infection, physical damage, and so on.

Apart from growth promoters, which act directly, other agents have been described which act in synergy with growth factors. ${ }^{21} 22$ Interleukin 1 is such an agent. Multipotent stem cells, for example, do not respond to macrophage colony stimulating factor; nor do they survive or develop in the presence of interleukin 1. But when stem cells are cultured in the presence of both macrophage colony stimulating factor and interleukin 1 they are stimulated to produce colonies containing mature macrophages. Similarly, interleukin 1 can synergise with granulocyte and macrophage colony stimulating factor and with interleukin 3 to "recruit" more stem cells to a state in which they can respond to the respective growth promoter ${ }^{22}$ (T M Dexter, unpublished observations). Thus interleukin 1 may have a major role in differentiation and commitment of stem cells. Furthermore, since most cells in the body produce interleukin 1 (and many cells in the body have receptors for interleukin 1) this molecule may be important not only in haemopoiesis but also in modulating growth and development in other tissues.

\section{Effects of haemopoietic growth promoters on animals}

Of fundamental importance is to determine the biochemical and molecular events which are driven by these various growth modifiers. Molecular cloning of the genes for many of these factors ${ }^{24}{ }^{29}$ has facilitated the production of large amounts of material from bacteria, which has been used to study the effects of haemopoietic growth promoters on animals. The effects are dramatic. Interleukin 3 stimulates stem cell proliferation in vivo ${ }^{30} 31$; granulocyte and macrophage colony stimulating factor stimulates marrow haemopoiesis and induces a fivefold to tenfold increase in circulating blood leucocytes ${ }^{32}$; granulocyte colony stimulating factor induces a pronounced increase in the numbers of stem cells, committed myeloid progenitor cells, and circulating blood neutrophils (tenfold to twentyfold) ${ }^{33}{ }^{34}$; and interleukin 1 can protect mice from potentially lethal radiation without the use of a marrow graft.

From a clinical point of view several other observations are noteworthy. Firstly, infusion of granulocyte and macrophage colony stimulating factor in a monkey with aplasia caused by a viral infection led to a rapid increase in circulating lymphoid and myeloid cells and to a resolution of the aplasia during treatment with growth factor. ${ }^{32}$ Secondly, injections of granulocyte colony stimulating factor in mice completely prevented the leucocyte nadir seen after chemotherapy with cyclophosphamide. ${ }^{33}$ Thirdly, administration of granulocyte and macrophage colony stimulating factor to monkeys after marrow transplantation led to a substantially earlier recovery of neutrophil concentrations in the blood (D Nathan, personal communication). In other words, the administration of growth factors was of major benefit in these three examples of life threatening conditions.

The potential benefits of growth factors are obvious, and much work is being done to investigate the various diseases in which growth factors can be of clinical benefit. Indeed, the first phase I and II clinical trials are now in progress using granulocyte and macrophage colony stimulating factor and granulocyte colony stimulating factor in patients with solid tumours undergoing treatment with aggressive chemotherapy. As damage to the haemopoietic system induced by chemotherapy is dose limiting in many therapeutic regimens the objective in treating with growth factors is to maintain circulating leucocyte concentrations above a critical baseline. The early results are encouraging. Moreover, the work emphasises how an understanding of the structure of regenerating systems has led to the discovery of the various regulatory influences controlling its development and the use of these agents to alleviate damage and to promote function.

\section{References}

1 Cronkite EP, Feinendegen LE. Notions about human stem cells. Blood Cells 1976;2:263-84 2 Lord BI, Potten CP, Cole RJ. Stem cells and tissue homeostasis. Cambridge: Cambridge University Press, 1978.

3 Hellman S, Botnick LE. Stem cell depletion: an explanation of the late effects of cytotoxins. Int $\mathcal{f}$ Radiat Biol 1977;2:181-4.

4 Rosendaal M, Hodgson GS, Bradley TR. Organisation of haemopoietic stem cells: the generationage hypothesis. Cell Tissue Kinet 1979;12:17-30.

5 Schofield $\mathbf{R}$. The relationship between the haemopoietic stem cell and the spleen colony forming cell: a hypothesis. Blood Cells 1978;4:7-25.

6 Ross EAM, Anderson N, Micklem HS. Serial depletion and regeneration of the murine hematopoietic system: implications for hematopoietic organisation and the study of aging. hematopoietic system: implictic

7 Harrison DE, Astle CM. Loss of stem cell repopulating ability upon transplantation. $\mathcal{F}$ Exp Med 1982;156:1767-79.

8. Dexter TM, Spooncer E, Schofield R, Lord BI, Simmons P. Haemopoietic stem cells and the problem of self-renewal. Blood Cells 1984;10:315-39.

9 Metcalf D, Moore MAS. Haemopoietic cells. Amsterdam: North Holland Publishing Co, 1971.

10 Hardisty RM, Weatherall DJ. Blood and its disorders. Oxford: Blackwell Scientific Publications, 1974.

11 Abramson S, Miller RG, Phillips RA. The identification in adult bone marrow of plutipotent and restricted stem cells of the myeloid and lymphoid lineages. 7 Exp Med 1979;145:1567-79.

12 Till JE, McCulloch EA. Haemopoietic stem cell differentiation. Biochem Biophys Acta 1980;605: 431-59.

13 Lemischka IR, Raulet DH, Mulligan RC. Developmental potential and dynamic behaviour of hematopoietic stem cells. Cell 1986;45:917-27.

14. Schofield R. The pluripotent stem cell. Clin Haematol 1979;8:221-37.

15 Metcalf D. Hemopoietic colonies. Berlin: Springer-Verlag, 1977.

16 Metcalf $D$. The granulocyte-macrophage colony stimulating factors. Science 1985;229:16-27.

17 Dexter TM. The message in the medium. Nature 1984;309:746-7.

18 Whetton AD, Dexter TM. Hemopoietic growth factors. Trends in Biochemical Science 1986;11:207-11.

19 Dexter TM, Moore M. Growth and development in the haemopoietic system: the role of lymphokines and their possible therapeutic potential in disease and malignancy. Carcinogenesis 1986;7:509-16.

20 Burgess AW, Nicola WA. Growth factors and stem cells. London: Academic Press, 1983.

21 Bradley TR, Hodgson GS. Detection of primitive macrophage progenitor cells in mouse bone marrow. Blood 1979;54:1446-50.

22 Stanley ER, Bartocci DP, Rosendaal M, Bradley TR. Regulation of very primitive multipotent hemopoietic cells by hemopoietin-1. Cell 1986;45:667-74.

23 Moore MAS, Warren DJ. Interleukin-1 and G-CSF synergism: in vivo stimulation of stem and recovery and hematopoietic regeneration following 5-fluorouracil treatment of mice. Proc Natl Acad Sci USA (in press).

24 Gough NM, Gough J, Metcalf D, Kelso A, Grail A. Molecular cloning of cDNA encoding a murine haemopoietic growth regulator, granulocyte/macrophage colony stimulating factor. Nature 1984;309:763-7.

25 Jacobs K, Shoemaker C, Rugersdorf R, Neill SD, Kaufman RJ. Isolation and characterisation of genomic and cDNA clones of human erythropoietin. Nature 1985;313:806-10.

26 Kawasaki ES, Ladner MB, Wang EM, van Arsdell J, Waffen MK. Molecular cloning of a cDNA encoding human macrophage-specific colony-stimulating factor (CSF-1). Science 1985;230: 291-6.

27 Souza LM, Boone TC, Gabrilove J, Lai PM, Zsebo KM. Recombinant human granulocyte colony-stimulating factor: effects on normal and leukemic myeloid cells. Science 1986;232:61-4.

28 Yang Y-C, Ciarletta AB, Temple PA, Chung MP, Kovacic S. Human IL-3 (multi-CSF): identification by expression cloning of a novel hematopoietic growth factor related to murine IL-3. Cell 1986;47:3-10.

29 Dexter TM. Out of the laboratory into clinical use. Nature 1986;321:198.

30 Lord BI, Molineux G, Testa NG, Kelly M, Spooncer E, Dexter TM. The kinetic response of haemopoietic precursor cells, in vivo, to highly purified recombinant interleukin-3. Lymphokine Research 1986;5:97-104.

31 Kindler V, Thorens B, de Kossodo S, Allet B, Eliason JF. Stimulation of hematopoiesis in vivo by recombinant bacterial murine interleukin-3. Proc Natl Acad Sci USA 1986;83:1001-5.

32 Donahue RE, Wang EA, Stone DK, Kamen R, Wang GG. Stimulation of hematopoiesis in primates by continuous infusion of recombinant human GM-CSF. Nature 1986;321:872-5.

33 Moore MAS, Welte K, Gabrilove J, Souza L. Biological activities of recombinaant human granulocyte-colony stimulating factor (rhG-CSF) and tumour necrosis factor: in vivo and in vitro analysis. $B$ hut (in press).

34 Welte K, Bonilla MD, Gillio AP, et al. Recombinant human G-CSF: effects on hematopoiesis in normal and cyclophosphamide treated primates. $\mathcal{J} \operatorname{Exp} M e d$ (in press).

(Accepted 6 May 1987) 